\title{
Motivasi Kerja dan Kepuasan Kerja terhadap Kinerja Karyawan PT. XYZ melalui Disiplin Kerja sebagai Variabel Intervening
}

\author{
Irwan Desyantoro' ${ }^{1}$, Hardani Widhiastuti ${ }^{2}$ \\ 1,2Magister Psikologi, Universitas Semarang \\ Jl. Soekarno Hatta, Tlogosari Kulon, Pedurungan, Kota Semarang, Jawa Tengah \\ e-mail: irwan.desyantoro@gmail.com ${ }^{1}$
}

Article History:

Received

22 April 2021

Review

19 Mei 2021

Revised

10 Juni 2021

Accepted

11 Juni 2021

Published

23 Juni 2021

Reviewer A:

Fendy Suhariadi
Abstract. This study aims to analyze the relationship between work motivation, job satisfaction and work discipline on employee performance. The number of samples taken was 84 respondents. Sampling validity testing is done by loading factor test and average variance extracted (AVE) while reliability testing uses internal consistency test based on composite reliability values. Validity test with loading factor and AVE value shows a valid value. Reliability testing with internal consistency tests has a composite reliability value that meets the criteria. Based on the test results, all variable indicator statements have met the validity and reliability criteria. The results of hypothesis testing with SmartPLS 3.0 show that work motivation has a positive and significant effect on work discipline so that it has an impact on employee performance, job satisfaction has a positive and significant effect on work discipline so that it has an impact on employee performance. The analysis shows that work motivation, job satisfaction, and work discipline can have a direct or indirect effect on employee performance.

Keywords: Work Motivation, Job Satisfaction, Work Discipline, Employee Performance

Abstrak. Penelitian ini bertujuan menganalisis keterkaitan motivasi kerja, kepuasan kerja dan disiplin kerja terhadap kinerja karyawan. Jumlah sampel yang diambil sebanyak 84 responden. Pengujian validitas samperl dialkukan dengan uji loading factor dan average variance extracted (AVE) sedangkan pengujian reliabilitas menggunakan uji internal consistency berdasarkan nilai composite reliability. Uji validitas dengan loading factor dan nilai AVE menunjukkan nilai yang valid. Pengujian reliabilitas dengan uji internal consistency mempunyai nilai composite reliability yang memenuhi kriteria. Berdasarkan hasil pengujian, semua pernyataan indikator variabel telah memenuhi kriteria validitas dan reliabilitas. Hasil uji hipotesis dengan SmartPLS 3.0 menunjukkan bahwa motivasi kerja berpengaruh positif dan signifikan terhadap disiplin kerja sehingga berdampak pada kinerja karyawan, kepuasan kerja berpengaruh positif dan signifikan terhadap disiplin kerja sehingga berdampak pada kinerja karyawan. Analisis menunjukkan bahwa motivasi kerja, kepuasan kerja, dan disiplin kerja dapat berpangaruh terhadap kinerja karyawan baik secara langsung ataupun tidak langsung.

Katakunci: Motivasi Kerja, Kepuasan Kerja, Disiplin Kerja, Kinerja Karyawan 


\section{Pendahuluan}

Sumber daya manusia merupakan salah satu faktor yang harus ada dan relatif lebih penting di bandingkan faktor-faktor lainnya, karena hampir seluruh kegiatan operasional di dalam perusahaan serta dalam upaya mencapai tujuan dari perusahaan di perlukan karywana yang berkualitas. Salah satu bentuk usaha untuk mendorong peningkatan atau pencapaian tujuan perusahaan adalah dengan meningkatkan kinerja karyawan dengan cara pemberdayaan kompetensi kerja yang baik, dengan demikian akan diperoleh karyawan yang berkualitas dan memeiliki kinerja yang baik. Pekerjaan yang dilakukan dengan baik, sesuai dengan kemampuan dan jenis pekerjaan yang diberikan tentunya akan meningkatkan kinerja sehingga dapat mendorong peningkatan kualitas kerja.

Keberhasilan suatu perusahaan dalam mencapai hasil tergantung dari keahlian dan keandalan sumber daya manusia yang mengoperasikan unit-unit kerja yang dimiliki perusahaan. Untuk itu diperlukan kinerja yang tinggi dari pelaksana kegiatan tersebut. Afandi (2018) kinerja adalah hasil kerja yang dapat dicapai oleh seseorang atau kelompok orang dalam suatu perusahaan sesuai dengan wewenang dan tanggung jawab masingmasing dalam upaya pencapaian tujuan organisasi secara illegal, tidak melanggar hukum dan tidak bertentangan dengan moral dan etika. Sementara itu, Hasibuan (2019) juga berpendapat bahwa kinerja merupakan perbandingan antara hasil dengan masukan, peningkatan kinerja ini dapat dimungkinkan oleh adanya peningkatan efisiensi dan sistem kerja, teknik produksi dan adanya peningkatan keterampilan dari tenagakerjanya.

PT. XYZ merupakan pengembangan kota industri terbesar di Jawa Tengah yang memiliki visi kota terintegrasi penuh yang menawarkan layanan \& keamanan berkualitas tinggi. PT. XYZ merupakan perusahaan patungan antara dua pengembang industri di Asia Tenggara. Pemerintah Indonesia menetapkan PT. XYZ sebagai salah satu Proyek Strategis Nasional, dan mempercepat pembangunan infrastruktur makro dan mikro. Oleh karena itu, Kementerian Koordinator Bidang Perekonomian memantau dan mengevaluasi pelaksanaan Proyek Strategis Nasional dan melaporkan kepada Presiden minimal enam bulan sekali. Saat ini karyawan Karyawan PT. XYZ dituntut agar bekerja dengan baik sehingga target pencapaian dalam kerja dapat meningkat. Barkaitan dengan target pencapaian dalam kerja khususnya pada bagian tiap devisi PT. XYZ kinerja karyawan dapat dilihat dari pencapaian hasil kerja baik secara kualitas maupun kuantitas dalam melaksanakan pekerjaannya sesuai dengan uraian tugas masing-masing bagian. Data dari 
performance appraisal karyawan PT. XYZ pada tahun 2017-2019 disajikan pada tabel dibawah ini.

Tabel 1. Data Rata-rata Performance Appraisal Karyawan PT. XYZ tahun 2017 2019

\begin{tabular}{c|c|c|c|c}
\hline Nilai & 2017 & 2018 & 2019 & Rata-rata \\
\hline E & $10 \%$ & $0 \%$ & $12 \%$ & $7 \%$ \\
\hline D & $25 \%$ & $2 \%$ & $16 \%$ & $14 \%$ \\
\hline C & $50 \%$ & $13 \%$ & $49 \%$ & $37 \%$ \\
\hline B & $10 \%$ & $72 \%$ & $23 \%$ & $35 \%$ \\
\hline A & $5 \%$ & $13 \%$ & $0 \%$ & $6 \%$ \\
\hline
\end{tabular}

Sumber: Data Performance appraisal PT. XYZ

Berdasarkan tabel tersebut bahwa data dalam kinerja karyawan pada PT. XYZ saat ini terjadi fluktuasi kinerja karyawan dari tahun ke tahun. Dari tahun 2017 PA mendapat kategori C dan naik di tahun 2018 manjadi B, namun di tahun berikutnya pada tahun 2019 mengalami penurunan kembali ke kategori $\mathrm{C}$ dengan hasil wawancara pada bagian HRD pada 19 September 2020 bahwa masih adanya terjadi fluktuasi dan belum memenuhi harapan perusahaan dalam target pencapaian yang nantinya akan memepengaruhi pencapaian dari visi misi menjadi terhambat. Terjadinya fluktuasi pada performance karyawan dalam bekerja akan berdampak pada perusahaan yang dapat membuat target pencapaian terhambat.

Salah satu faktor yang sangat berpengaruh dalam sumber daya manusia adalah faktor disiplin. Menurut Sedarmayanti (2017) mengatakan bahwa faktor-faktor yang memengaruhi kinerja adanya sikap mental, pendidikan, ketrampilan, kepemimpinan, tingkat penghasilan, kedisiplinan, komunikasi, sarana prasarana, kesempatan berprestasi. Hasibuan (2019) menjelaskan bahwa kedisiplinan adalah kesadaran dan kesediaan seseorang manaati semua peraturan perusahaan dan norma-norma sosial yang berlaku. Kedisiplinan diartikan jika karyawan selalu datang dan pulang tepat waktunya, mengerjakan semua pekerjaannya dengan baik, mamtuhi semua peraturan perusahaan dan norma-norma sosial yang berlaku. Disiplin kerja merupakan salah satu hal yang berpengaruh pada tingkat kinerja seorang individu dalam suatu perusahaan. Menurut Darmawan (2013) disiplin kerja diartikan sebagai suatu sikap, tingkah laku dan perbuatan sesuai peraturan dari organisasi dalam bentuk tertulis maupun tidak. Selain itu disiplin kerja dapat dikatakan hal yang paling penting dalam suatu organisasi, karena keberhasilan suatu organisasi dapat diukur seberapa besar kedisiplinan karyawannya.

Beberapa aspek-aspek disiplin kerja menurut Sinungan (2014) antara lain adanya hasrat yang kuat, adanya perilaku yang dikendalikan, dan adanya kepatuhan serta 
ketaatan terjadap ketentuan yang sudah ada dan berlaku. Ini diperkuat dengan adanya penelitian Tyas dan Sunuharyo (2018) ; Syardiansah dan Utami (2019) ; Kasino dan Indrayanti (2020) dalam hasil penelitian yang mengatakan bahwa disiplin kerja berpengaruh positif dan signifikan terhadap kinerja karyawan dan disiplin kerja memiliki pengaruh yang paling dominan terhadap kinerja karyawan. Semakin tinggi kedisiplinan karyawan dalam bekerja maka kinerja karyawan dalam kerjapun akan semakin tinggi pula.

Disiplin dalam bekerja dan kinerja karyawan menjadi masalah yang cukup kompleks dimana tingkat produktivitas kerja dapat dipengaruhi sejumlah faktor seperti kemauan karyawan (motivasi kerja) dan adanya kepuasan dalam bekerja di organisasi. Motivasi kerja dan kepuasan kerja dapat meningkatkan disiplin kerja karyawan, ketika karyawan mempunyai motivasi baik internal ataupun eksternal dan karyawan akan merasa puas dalam bekerja maka disiplin kerja pun akan baik pula.

Robbins (2015) mendefinisikan motivasi sebagai keinginan untuk melakukan sebagai kesediaan untuk mengeluarkan tingkat upaya yang tinggi untuk tujuan-tujuan organisasi, yang dikondisikan oleh kemampuan upaya itu untuk memenuhi suatu kebutuhan individual. Adapula elemen-elemen motivasi kerja menurut Robbins dan Judge (2009) ; Sedarmayanti (2017) yaitu intensitas yang berhubungan dengan seberapa giat seseorang berusaha, arah yang berhubungan dengan upaya yang diarahkan dan konsisten dengan tujuan-tujuan organisasi, ketekunan merupakan ukuran mengenai berapa lama seseorang bisa mempertahankan usahanya demi mencapai tujuan mereka. Sedangkan mengenai kepuasan kerja Handoko (2010) menjelaskan bahwa kepuasan kerja mencerminkan perasaan seseorang terhadap pekerjaannya yang tampak dalam sikap positif karyawan terhadap pekerjaan dan segala sesuatu yang dihadap di lingkungan kerjanya. Menurut Job Satisfaction Survey (JSS) yang dikembangkan oleh Spector (Mas'ud, 2014) dalam American Journal of Community Psychology, aspek-aspek kepuasan kerja yaitu komitmen organisasional, karakteristik pekerjaan, perilaku pimpinan, keinginan untuk resign, karakteristik individu. Dalam penelitian tentang motivasi dan kepuasan kerja yang dapat meningkatkan disiplin kerja seperti pada hasil penelitian Kurniasari \& Maulana (2019); Rohana \& Akos (2019) bahwa motivasi dan kepuasan kerja dapat mempengaruhi disiplin kerja. Semakin tinggi motivasi dan kepuasan kerja maka semakin tinggi pula disiplin kerjanya sebaliknya jika motivasi dan kepuasan kerja rendah maka disiplin kerja karyawan akan juga rendah. 
Mengingat pentingnya motivasi dan kepuasan kerja yang dirasakan karyawan dan kedisiplinan dalam bekerja terhadap kinerja karyawan pada PT. XYZ, maka berdasarkan pemaparan di atas, peneliti tertarik untuk melakukan penelitian dan pengkajian secara lebih mendalam tentang pengaruh motivasi kerja dan kepuasan kerja terhadap kinerja karyawan dengan kedisiplinan sebagai variabel intervening. Dalam penelitian ini disiplin kerja diharapkan mampu memediasi antara motivasi kerja dan kepuasan kerja terhadap kinerja karyawan. Seseorang dengan disiplin kerja yang tinggi akan memiliki sikap mematuhi peraturan dan selalu tepat waktu dalam mengerjakan tugas sesuai dengan tanggung jawabnya dalam bekerja yang pada akhirnya akan berdampak pada peningkatan kinerja. Disiplin kerja merupakan hal penting yang harus memperoleh perhatian perusahaan karena seseorang yang tidak memiliki kedisiplinan dalam bekerja yang tinggi kemungkinan besar tidak akan memiliki cukup motivasi kerja dan kepuasan kerja yang tinggi dalam bekerja.

\section{Metode}

Penelitian ini menggunakan metode kuantitatif, dengan teknik analisis jalur (path analysis). Populasi dalam penelitian adalah karyawan PT. XYZ yang berjumlah 84 orang. Pada penelitian ini menggunakan teknik studi populasi atau sampel jenuh. Sugiyono (2010) mengemukakan bahwa teknik studi populasi atau sampel jenuh adalah teknik penentuan sampel bila semua anggota populasi digunakan sebagai sampel. Peneliti menggunakan semua karyawan atau tim di PT. XYZ yang berjumlah 84 orang sebagai responden yang terdiri dari 52 laki-laki dan 32 perempuan. Pengambilan sampel penelitian berdasarkan divisi organisasi antara lain, Development \& Contruction, Sales \& Marketing, Township Management, Corporate Services, Finance \& Accounting. Instrumen yang digunakan adalah skala model Likert. Analisis data dibantu menggunakan program SmartPLS.

\section{Hasil}

\section{Pengujian Outer Loading Factor}

Nilai loading factor sebesar 0,50 atau lebih dianggap memiliki validasi yang cukup kuat untuk menjelaskan konstruk laten (Hair et al, 2010). Nilai outer loading awal pada variabel motivasi kerja (X1), kepuasan kerja (X2), disiplin kerja (Z) dan kinerja karyawan (Y) dapat dilihat pada tabel 9. Menurut Yamin dan Kurniawan (2011) indikator yang memiliki nilai loading factor antara 0,5 - 0,6 dapat diterima. Outer loading factor yang memiliki nilai diatas 0,5 - 0,6 dapat dilihat pada tabel dibawah ini. 
Philanthropy Journal of Psychology

Vol 5 Nomor 1 (2021), 31-46

ISSN 2580-6076 (Print), ISSN 2580-8532 (Online)

Tabel 2. Outer Loading Akhir

\begin{tabular}{c|c|c|c|c|c|c|c}
\hline $\begin{array}{c}\text { No. } \\
\text { Aitem }\end{array}$ & $\begin{array}{c}\text { Motivasi } \\
\text { Kerja }\end{array}$ & $\begin{array}{c}\text { No. } \\
\text { Aitem }\end{array}$ & $\begin{array}{c}\text { Kepuasan } \\
\text { Kerja }\end{array}$ & $\begin{array}{c}\text { No. } \\
\text { Aitem }\end{array}$ & $\begin{array}{c}\text { Disiplin } \\
\text { Kerja }\end{array}$ & $\begin{array}{c}\text { No. } \\
\text { Aitem }\end{array}$ & $\begin{array}{c}\text { Kinerja } \\
\text { Karyawan }\end{array}$ \\
\hline X1.1 & 0.717 & X2.1 & 0.831 & Z1 & 0.860 & Y1 & 0.766 \\
X1.10 & 0.781 & X2.11 & 0.837 & Z11 & 0.832 & Y11 & 0.766 \\
X1.11 & 0.822 & X2.12 & 0.793 & Z13 & 0.860 & Y12 & 0.760 \\
X1.16 & 0.789 & X2.13 & 0.802 & Z14 & 0.806 & Y15 & 0.791 \\
X1.17 & 0.758 & X2.14 & 0.727 & Z16 & 0.813 & Y16 & 0.831 \\
X1.19 & 0.842 & X2.15 & 0.748 & Z17 & 0.709 & Y17 & 0.749 \\
X1.2 & 0.818 & X2.18 & 0.806 & Z2 & 0.859 & Y18 & 0.794 \\
X1.20 & 0.748 & X2.2 & 0.839 & Z20 & 0.823 & Y2 & 0.847 \\
X1.21 & 0.833 & X2.21 & 0.772 & Z21 & 0.819 & Y20 & 0.751 \\
X1.22 & 0.726 & X2.22 & 0.757 & Z23 & 0.825 & Y23 & 0.829 \\
X1.24 & 0.798 & X2.25 & 0.827 & Z25 & 0.875 & Y24 & 0.786 \\
X1.27 & 0.803 & X2.26 & 0.829 & Z26 & 0.847 & Y25 & 0.759 \\
X1.29 & 0.760 & X2.27 & 0.811 & Z27 & 0.741 & Y29 & 0.781 \\
X1.3 & 0.746 & X2.29 & 0.749 & Z28 & 0.817 & Y3 & 0.800 \\
X1.30 & 0.764 & X2.3 & 0.823 & Z29 & 0.787 & Y30 & 0.771 \\
X1.5 & 0.748 & X2.30 & 0.826 & Z3 & 0.840 & Y4 & 0.774 \\
X1.6 & 0.742 & X2.31 & 0.768 & Z31 & 0.777 & Y6 & 0.850 \\
X1.7 & 0.789 & X2.34 & 0.765 & Z37 & 0.707 & Y7 & 0.831 \\
& & X2.35 & 0.723 & Z38 & 0.808 & Y9 & 0.770 \\
& & X2.38 & 0.729 & Z39 & 0.788 & & \\
& & X2.4 & 0.837 & Z4 & 0.795 & & \\
& & X2.40 & 0.732 & Z40 & 0.774 & & \\
& & X2.6 & 0.759 & Z5 & 0.777 & & \\
& & X2.7 & 0.817 & Z6 & 0.829 & & \\
X2.9 & 0.819 & Z8 & 0.856 & & \\
& 0.739 & Z9 & 0.748 & & \\
& & & & & &
\end{tabular}

Sumber: Hasil penelitian, diolah dengan SmartPLS 3.0, 2021.

\section{Pungujian Konstruk Validitas dan Reliabilitas}

Instrumen reliabilitas dalam penelitian ini diukur dengan dua kriteria yaitu nilai composite reliability dan cronbach's alpha. Penggunaan cranbach's alpha cenderung menaksir lebih rendah reliabilitas variabel dibandingkan composite reliability sehingga disarankan untuk menggunakan composite reliability (Haryono, 2017). Sebuah konstruk dapat dikatakan reliabel apabila nilai cronbach's alpha lebih besar 0,70, sedangkan menurut Ghozali (2005) variabel dikatakan reliabel jika nilai composite reliability diatas 0,70. Nilai konstruk validitas dan reliabilitas dapat dilihat pada tabel berikut.

Tabel 3. Construct Validity and Reliability

\begin{tabular}{l|c|c|c|c}
\hline & $\begin{array}{c}\text { Cronbach's } \\
\text { Alpha }\end{array}$ & Rho_A & $\begin{array}{c}\text { Composite } \\
\text { Reliability }\end{array}$ & $\begin{array}{c}\text { Average Variance } \\
\text { Extracted (AVE) }\end{array}$ \\
\hline Disiplin Kerja & 0.979 & 0.979 & 0.980 & 0.653 \\
\hline Kepuasan Kerja & 0.975 & 0.977 & 0.977 & 0.621 \\
\hline Kinerja Karyawan & 0.967 & 0.969 & 0.969 & 0.625 \\
\hline Motivasi Kerja & 0.961 & 0.963 & 0.965 & 0.605 \\
\hline
\end{tabular}

Sumber: Hasil penelitian, diolah dengan SmartPLS 3.0, 2021. 
Berdasarkan tabel diatas menunjukkan bahwa semua variabel penelitian memiliki nilai composite reliability dan cronbach's alpha diatas 0,70 . Oleh karena itu indikator yang digunakan dalam variabel penelitian ini dikatakan reliable. Sedangkan untuk menguji validitas menggunakan nilai Average Variance Extracted (AVE) dengan nilai batas diatas 0,50. Pada tabel diatas terlihat bahwa semua variabel memiliki nilai AVE diatas 0,50. Hal ini dapat diartikan bahwa keseluruhan aitem dan variabel dinyatakan valid.

\section{Pengujian Validitas Diskriminan}

Uji korelasi diskriminan dilakukan untuk melihat korelasi anara konstruk dengan konstruk lainnya. Jika nilai akar kuadrat (square root of average) AVE setiap konstruk lebih besar daripada nilai korelasi antara konstruk dengan konstruk lainnya dalam model maka dapat disimpulkan bahwa konstruk memiliki tingakt validitas yang baik dan dapat dilihat pada tabel dibawah ini.

Tabel 4. Nilai Discriminat Validity

\begin{tabular}{l|c|c|c|c}
\hline & Disiplin Kerja & $\begin{array}{c}\text { Kepuasan } \\
\text { Kerja }\end{array}$ & $\begin{array}{c}\text { Kinerja } \\
\text { Karyawan }\end{array}$ & Motivasi Kerja \\
\hline Disiplin Kerja & 0.808 & & & \\
\hline Kepuasan Kerja & 0.635 & 0.788 & & \\
\hline Kinerja Karyawan & 0.696 & 0.596 & 0.791 & 0.778 \\
\hline Motivasi Kerja & 0.661 & 0.501 & 0.557 & 0
\end{tabular}

Sumber: Hasil Penlitian, diolah dengan SmartPLS 3.0, 2021

Pada tabel diatas perbandingan dari nilai akar AVE memperlihatkan bahwa masing-masing dari nilai tersebut lebih besar dibandingkan dengan korelasi antar variabel lainnya, sehingga dapat ditarik kesimpulan bahwa semua variabel laten dalam penelitian memiliki discriminant validity yang baik.

\section{Pengujian Hipotesis}

\section{a. Analisis Structural Model}

Pengujian structural model dilakukan untuk melihat hubungan konstruk, nilai signifikansi dan $R$ square dari model penelitian. Nilai $R$-Square dapa digunakan untuk menilai pengaruh variabel independen tertentu terhadap variabel dependen. Nilai estimasi $R$-Square dapat dilihat pada tabel dibawah ini.

\section{Tabel 5. Nilai R-Square}

\begin{tabular}{c|c|c}
\hline & R-Square & R-Square Adjusted \\
\hline Disiplin Kerja & 0,560 & 0,549 \\
\hline Kinerja Karyawan & 0,535 & 0,518 \\
\hline
\end{tabular}

Sumber: Hasil Penelitian, diolah dengan SmartPLS 3.0, 2021

Berdasarkan tabel diatas diketahui bahwa nilai $R$-Square untuk variabel disiplin kerja sebesar 0,560 yang dapat diinterpretasikan bahwa besarnya pengaruh variabel 
motivasi kerja dan kepuasan kerja terhadap disiplin kerja adalah 56,0\% sedangkan sisanya $44 \%$ dijelaskan oleh variabel lain di luar penelitian ini. Nilai $R$-Square untuk variabel kinerja karyawan sebesar 0,535 yang artinya bahwa 53,5\% variabel kinerja karyawan dipengaruhi oleh variabel motivasi kerja, kepuasan kerja dan disiplin kerja, sedangkan sisanya sebesar 53,5\% dipengaruhi oleh variabel di luar penelitian ini.

\section{b. Analisis Pengaruh Langsung}

Diterima atau tidaknya sebuah hipotesis yang diajukan, perlu dilakukan pengujian hipotesis dengan menggunakan fungsi Bootstrapping pada SmartPLS 3.0. Hipotesis diterima pada tingkat signifikansi lebih kecil dari 0,05 atau t-value melebihi nilai kritisnya (Hair et al, 2006). Nilai t statistics untuk tingkat signifikansi 5\% sebesar 1,66. Hasil analisis data penelitian dapat dilihat pada tabel dibawah ini.

Tabel 6. Hasil Path Coefficient

\begin{tabular}{c|l|c|c|c|c|c|c}
\hline & \multicolumn{1}{|c|}{ Variabel/Konstruk } & $\begin{array}{c}\text { Original } \\
\text { Sample }\end{array}$ & $\begin{array}{c}\text { Sample } \\
\text { Mean }\end{array}$ & $\begin{array}{c}\text { Standard } \\
\text { Deviation }\end{array}$ & $\begin{array}{c}\text { T } \\
\text { Statistics }\end{array}$ & $\begin{array}{c}\text { P } \\
\text { Values }\end{array}$ & Hasil \\
\hline H1 & $\begin{array}{l}\text { Motivasi Kerja } \rightarrow \\
\text { Disiplin Kerja }\end{array}$ & 0.457 & 0.460 & 0.098 & 4.678 & 0.000 & Diterima \\
\hline H2 & $\begin{array}{l}\text { Motivasi } \rightarrow \text { Kinerja } \\
\text { Karyawan }\end{array}$ & 0.136 & 0.140 & 0.136 & 1.004 & 0.316 & Ditolak \\
\hline H3 & $\begin{array}{l}\text { Kepuasan Kerja } \rightarrow \\
\text { Disiplin Kerja }\end{array}$ & 0.406 & 0.404 & 0.093 & 4.382 & 0.000 & Diterima \\
\hline H4 & $\begin{array}{l}\text { Kepuasan Kerja } \rightarrow \\
\text { Kinerja Karyawan }\end{array}$ & 0.239 & 0.239 & 0.097 & 2.461 & 0.014 & Diterima \\
\hline H5 & $\begin{array}{l}\text { Disiplin Kerja } \rightarrow \\
\text { Kinerja Karyawan }\end{array}$ & 0.454 & 0.453 & 0.147 & 3.080 & 0.002 & Diterima \\
\hline
\end{tabular}

Sumber: Hasil Penelitian, diolah dengan SmartPLS 3.0, 2021

\section{c. Analisis Pengaruh tidak Langsung (Mediasi)}

Untuk melihat apakah disiplin kerja memediasi antara motivasi kerja dan kepuasan kerja terhadap kinerja karyawan. Hubungan variabel independen terhadap variabel dependen melalui variabel mediasi atau intervening pada penelitian ini dapat dilihat pada Tabel dibawah ini.

Tabel 7. Specific Indirect Effect

\begin{tabular}{c|l|c|c|c|c|c|c}
\hline & Variabel/Konstruk & $\begin{array}{c}\text { Original } \\
\text { Sample }\end{array}$ & $\begin{array}{c}\text { Sample } \\
\text { Mean }\end{array}$ & $\begin{array}{c}\text { Standard } \\
\text { Deviation }\end{array}$ & $\begin{array}{c}\text { T } \\
\text { Statistics }\end{array}$ & P Values & Hasil \\
\hline H6 & $\begin{array}{l}\text { Motivasi Kerja } \rightarrow \\
\text { Disiplin Kerja } \rightarrow \\
\text { Kinerja Karyawan }\end{array}$ & 0,208 & 0,213 & 0,094 & 2,209 & 0,028 & Diterima \\
\hline H7 & $\begin{array}{l}\text { Kepuasan Kerja } \rightarrow \\
\text { Disiplin Kerja } \rightarrow \\
\text { Kinerja Karyawan }\end{array}$ & 0,185 & 0,181 & 0,068 & 2,703 & 0,007 & Diterima \\
\hline
\end{tabular}

Sumber: Hasil penelitian, diolah dengan SmartPLS 3.0, 2021. 


\section{Pembahasan dan Diskusi}

\section{Hubungan Motivasi Kerja dengan Disiplin Kerja}

Dari pengujian hasil penelitian, terdapat pengaruh yang positif dan signifikan antara motivasi kerja dengan disiplin kerja di PT. XYZ. Hal ini sesuai dengan hasil path coefficients dengan nilai original sampel 0,457 yang menunjukkan angka positif dengan nilai t-hitung 4,678 lebih besar dari nilai t-tabel 1,66 dan nilai p-value 0,000 lebih kecil dari 0,05 sehingga dapat dikatakan variabel motivasi kerja berpengaruh signifikan terhadap disiplin kerja. hasil ini dapat diinterpretasikan bahwa semakin tinggi motivasi kerja maka disiplin kerja tersebut akan semakin baik atau meningkat dan sebaliknya jika motivasi kerja rendah maka disiplin kerja terhadap aturan tersebut akan buruk.

Hubungan antara motivasi kerja sangat penting dalam upaya meningkatkan kinerja karyawan. Rendahnya motivasi kerja yang diberikan terhadap pemberdayaan sumber daya manusia akan mempengaruhi kinerja anggota organisasi dalam memberikan pelayanan yang professional kepada konsumen. Hasibuan (2019) menjelaskan bahwa kedisiplinan adalah kesadaran dan kesediaan seseorang manaati semua peraturan perusahaan dan norma-norma sosial yang berlaku. Kedisiplinan diartikan jika karyawan selalu datang dan pulang tepat waktunya, mengerjakan semua pekerjaannya dengan baik, mamtuhi semua peraturan perusahaan dan norma-norma sosial yang berlaku.

Disiplin kerja merupakan salah satu hal yang berpengaruh pada tingkat kinerja seorang individu dalam suatu perusahaan. Menurut Darmawan (2013) disiplin kerja diartikan sebagai suatu sikap, tingkah laku dan perbuatan sesuai peraturan dari organisasi dalam bentuk tertulis maupun tidak. Selain itu disiplin kerja dapat dikatakan hal yang paling penting dalam suatu organisasi, karena keberhasilan suatu organisasi dapat diukur seberapa besar kedisiplinan karyawannya. Karyawan juga harus patuh dan tunduk pada norma-norma yang berlaku pada organisasi karena semakin baik kedisiplinan karyawan maka semakin tinggi kinerja yang dapat dicapainya.

Penelitian ini sesuai dengan penelitian sebelumnya, bahwa motivasi kerja berpengaruh positif terhadap disiplin kerja (Pratama dan Nurbudiawati, 2016; Andry, 2018; Saputra, 2019; Anggraeni dkk, 2019). Motivasi ini adalah pendorong kerja yang bersumber dari dalam diri pekerja sebgai individu, berupa kesadaran mengenai kepentingannya akan manfaat/makna pekerjaan yang dilaksanakannya. Misalnya adalah pekerjaan yang bekerja secara berdedikasi semata-mata karenan merasa memperoleh kesempatan-kesempatan mengaktualisasi atau mewujudkan dirinya secara maksimal. 


\section{Hubungan Motivasi Kerja dengan Kinerja Karyawan}

Hasil pengujian menunjukkan bahwa tidak terdapat pengaruh yang signifikan antara motivasi kerja terhadap kinerja karyawan di PT. XYZ. Hal ini sesuai dengan hasil path coefficients dengan nilai original sampel 0,136 yang menunjukkan angka positif dimana nilai t-statistik motivasi kerja terhadap kinerja karyawan 1,004 lebih kecil dari nilai t-tabel 1,66 atau dapat dilihat dari nilai p-value nya yang bernilai 0,316 lebih besar dari 0,05. Naik turunnya motivasi kerja tidak begitu mempengaruhi kinerja karyawan. Hasil penelitian ini didukung dengan penelitian sebelumnya, bahwa motivasi kerja tidak berpengaruh signifikan terhadap kinerja karyawan secara partial (Safitri dan Sutjahjo, 2020; Maharani dan Suhardi, 2020).

\section{Hubungan Kepuasan Kerja dengan Disiplin Kerja}

Terdapat pengaruh yang positif dan siginifikan antara kepuasan kerja terhadap disiplin kerja di PT. XYZ. Hal ini sesuai dengan hasil path coefficients dengan nilai original sampel 0,406 yang menunjukkan angka positif dengan nilai t-hitung 4,382 lebih besar dari nilai t-tabel 1,66 dan nilai p-value 0,000 lebih kecil dari 0,05 sehingga dapat dikatakan variabel kepuasan kerja berpengaruh signifikan terhadap disiplin kerja. hasil ini dapat diinterpretasikan bahwa semakin baik kepuasan kerja maka disiplin kerja tersebut akan semakin baik atau meningkat dan sebaliknya jika kepuasan kerja buruk maka disiplin kerja terhadap aturan tersebut akan mejadi buruk pula.

Perasaan tidak puas yang dirasakan karyawan terhadap pekerjaannya menimbulkan motif untuk berperilaku tidak disiplin. Lateiner (2002) menjelaskan disiplik kerja sebagai suatu tingkah laku yang menunjukkan ketaatan individu pada peraturan yang berlaku dalam melakukan tugas sangat diharapkan dalam melaksanakan tugas untuk mewujudkan tujuan organisasi dan sekaligus menjadi sarana untuk mempertahankan eksistensi organisasi. Lateiner (2002) menyatakan disiplij kerja berkiatan dengan ketepatan waktu, kemampuan dalam menghasilkan kualitas dan kuantitas kerja yang memuaskan serta semangat kerja dalam menghasilkan suatu pekerjaan. Ketidakpuasan yang dirasakan karyawan ditunjukkan dengan disiplin kerja yang rendah atau tidak dipatuhinya aturan-aturan yang telah ditetapkan perusahaan. Menurut Lateiner (2002) kondisi disiplin karyawan yang baik adalah menghasilkan jumlah dan kualitas pekerjaan yang memuaskan dana juga mengikuti cara kerja yang ditentukan oleh perusahaan. Hal ini sesuai dengan penelitian sebelumnya, bahwa kepuasan kerja berpengaruh positif terhadap disiplin kerja (Nizar, 2016; Manik, 2017; Iskandar, 2018; Rahmania dan Widawati, 2020). 


\section{Hubungan Kepuasan Kerja dengan Kinerja Karyawan}

Dari pengujian hasil penelitian, terdapat pengaruh yang positif dan signifikan antara kepuasan kerja dengan kinerja karyawan di PT. XYZ. Hal ini sesuai dengan hasil path coefficients dengan nilai original sampel 0,239 yang menunjukkan angka positif dengan nilai t-hitung 2,461 lebih besar dari nilai t-tabel 1,66 dan nilai p-value 0,014 lebih kecil dari 0,05 sehingga dapat dikatakan variabel kepuasan kerja berpengaruh signifikan terhadap kinerja karyawan. hasil ini dapat diinterpretasikan bahwa semakin karyawan merasa puas dalam bekerja maka kinerja karyawan tersebut akan semakin baik atau meningkat dan sebaliknya jika karyawan merasa tidak puas dalam bekerja maka kinerja karyawan menurun.

Seoarang dihadapkan pada suatu keadaan yang sesuai atau tidak dengan keinginannya akan dapat mempengaruhi peningkatan kinerja seoarang karyawan. Kepuasan kerja dan kinerja karyawan akan memacu karyawan menjadi lebih produktif. Secara ringkas dapat dikatakan bahwa pengaruh kepuasan kerja dengan kinerja karyawan adalah pernyataan : "seorang pekerja yang bahagia adalah seorang pekerja yang produktif atau produktivitas menghasilkan kepuasan". Jika diterapkan dalam suatu organisasi maka dapat dikatakan organisasi dengan karyawan yang terpuaskan cenderung lebih efektif, sehingga produktivitas semakin meningkat (Robbins, 2009)

Hal ini sejalan dengan penelitian Arda (2017); Purba, dkk (2019); Mokoagow, dkk (2020); Cahyani, dkk (2020) yang menjelaskan bahwa kepuasan kerja terhadap kinerja karyawan berpengaruh positif signifikan dimana jika karyawan merasa puas dalam bekerja maka karyawan akan menghasilkan kinerja yang baik. Seorang karyawan dihadapkan pada suatu keadaan yang sesuai atau tidak dengan keinginannya akan dapat memacu karyawan menjadi lebih produktif.

\section{Hubungan Disiplin Kerja dengan Kinerja Karyawan}

Terdapat pengaruh yang positif dan siginifikan antara disiplin kerja terhadap kinerja karyawan di PT. XYZ. Hal ini sesuai dengan hasil path coefficients dengan nilai original sampel 0,454 yang menunjukkan angka positif dengan nilai t-hitung 3,080 lebih besar dari nilai t-tabel 1,66 dan nilai p-value 0,002 lebih kecil dari 0,05 sehingga dapat dikatakan variabel disiplin kerja berpengaruh signifikan terhadap kinerja karyawan. hasil ini dapat diinterpretasikan bahwa semakin baik disiplin karyawan dalam bekerja maka kinerja karyawan tersebut akan semakin baik atau meningkat dan sebaliknya jika disiplin kerja karyawan buruk atau menurun maka kinerja karyawan tersebut akan mejadi buruk pula. 
Hal tersebut sesuai dengan pendapat menurut Hasibuan (2019) disiplin kerja merupakan fungsi operatif menajemen sumber daya manusia yang terpenting, karena semakin baik disiplin kerja karyawan maka semakin tinggi prestasi kerja yang dapat dicapainya, sedangkan apabila tidak adanya penerapan disiplin kerja yang baik akan sulit bagi pesuahaan untuk mencapai hasil yang optimal.

Penelitian terdahulu Syarkani (2017); Husain (2018); Mailana, dkk (2018); Tyas dan Sunuharyo (2018) menjelaskan bahwa disiplin kerja terhadap kinerja karyawan berpengaruh positif yang signifikan artinya jika karyawan berperilaku disiplin dalam bekerja maka kinerja karyawan akan menjadi lebih baik dan meningkat. Ketaatan pada peraturan akan membuat kenyamanan dan kelancaran karyawan dalam bekerja. Karyawan yang patuh terhadap peraturan akan memahami peraturan yang berlaku dan memahami konsekuensi apabila melakukan tindakan indisipliner yang membuat mereka berperilaku disiplin dalam bekerja sehingga kinerja karyawan meningkat.

\section{Hubungan Motivasi Kerja terhadap Kinerja Karyawan dengan Disiplin Kerja sebagai Variabel Intervening}

Terdapat pengaruh yang positif dan signifikan antara motivasi kerja terhadap kinerja karyawan melalui disiplin kerja. Hal ini sesuai dengan hasil path coefficients dengan nilai original sampel 0,208 yang menunjukkan angka positif dengan nilai t-statistik 2,209 lebih besar dari 1,66 dan p-value 0,028 dari 0,05. Sehingga dapat dikatakan variabel motivasi kerja berpengaruh signifikan terhadap variabel kinerja karyawan dengan disiplin kerja sebagai variabel intervening. Kinerja karyawan akan berdampak baik apabila motivasi kerja tinggi dan dapat meningkatkan disiplin kerja sehingga produktivitas kerja atau kinerja karyawan juga akan tinggi.

\section{Hubungan Kepuasan Kerja terhadap Kinerja Karyawan dengan Disiplin Kerja sebagai Variabel Intervening}

Dari pengujian hasil penelitian, terdapat pengaruh yang positif dan signifikan antara kepuasan kerja terhadap kinerja karyawan melalui disiplin kerja di PT. XYZ. Hal ini sesuai dengan hasil path coefficients dengan nilai original sampel 0,185 yang menunjukkan angka positif dengan nilai t-statistik 2,703 lebih besar dari 1,66 dan p-value 0,007 dari 0,05. Sehingga dapat dikatakan variabel kepuasan kerja berpengaruh signifikan terhadap variabel kinerja karyawan dengan disiplin kerja sebagai variabel intervening. Kinerja karyawan akan berdampak baik apabila kepuasan kerja tinggi dan dapat meningkatkan disiplin kerja sehingga produktivitas kerja atau kinerja karyawan juga akan tinggi. 


\section{Simpulan}

Kesimpulan pada penelitian ini adalah sebagai berikut.

1. Motivasi kerja berpengaruh positif dan signifikan terhadap disiplin kerja di PT. XYZ. Artinya semakin tinggi motivasi kerja maka semakin tinggi pada disiplin kerja. sebaliknya semakin rendah motivasi kerja maka semakin rendah pula disiplin kerjanya.

2. Motivasi kerja berpengaruh positif dan tidak signifikan terhadap kinerja karyawan di PT. XYZ tetapi akan berpengaruh signifikan apabila disiplin kerja memediasi motivasi kerja dengan kinerja karyawan.

3. Kepuasan kerja berpengaruh positif dan signifikan terhadap disiplin kerja di PT. XYZ. Artinya semakin tinggi kepuasan kerja maka semakin tinggi disiplin kerja. sebaliknya semakin rendah kepuasan kerja maka semakin rendah pula disiplin kerjanya.

4. Kepuasan kerja berpengaruh positif dan signifikan terhadap kinerja karyawan di PT. XYZ. Artinya semakin tinggi kepuasan kerja maka semakin tinggi kinerja karyawan. sebaliknya semakin rendah kepuasan kerja maka semakin rendah pula kinerja karyawan.

5. Disiplin kerja berpengaruh positif dan signifikan terhadap kinerja karyawan di PT. XYZ. Artinya semakin tinggi disiplin kerja maka semakin tinggi pada kinerja karyawan. sebaliknya semakin rendah disiplin kerja maka semakin rendah pula kinerja karyawan.

6. Motivasi kerja berpengaruh positif terhadap kinerja karyawan melalui disiplin kerja di PT. XYZ. Artinya ketika semakin tinggi motivasi kerja maka semakin tinggi disiplin kerja dan berdampak pada kinerja karyawan. Sebaliknya semakin rendah motivasi kerja maka disiplin kerja akan menurun dan berdampak pada kinerja karyawan.

7. Kepuasan kerja berpengaruh positif terhadap kinerja karyawan melalui disiplin kerja di PT. XYZ. Artinya ketika semakin tinggi kepuasan kerja maka semakin tinggi disiplin kerja dan berdampak pada kinerja karyawan. Sebaliknya semakin rendah kepuasan kerja maka disiplin kerja akan menurun dan berdampak pada kinerja karyawan.

\section{Kepustakaan}

Afandi, Pandi. 2018. Manajemen Sumber Daya Manusia Teori Konsep dan Indikator. Pekanbaru: Zanafa Publishing.

Andry. 2018. "Pengaruh Motivasi terhadap Disiplin dan Kinerja Pegawai pada Dinas Pendapatan Daerah Pekanbaru". JWEM. Volume 8, Nomor 2.

Anggraeni, Made Utari; Damayanti, Yeni dan N. Ndun, Helga J,. 2019. "Peran Motivasi Kerja terhadap Disiplin Kerja Aparat Kepolisian di Polsek Kelapa Lima Kota Kupang". Journal of Health and Behavior Sciene. Volume 1, Nomor 4. 
Arda, Mutia. 2017. "Pengaruh Kepuasan Kerja dan Disiplin Kerja terhadap Kinerja Karyawan pada Bank Rakyat Indonesia Cabang Putri Hijau Medan". Jurnal Ilmiah Manajemen \& Bisnis. Volume 18, Nomor 1.

Cahyani, Riris Anggun; Sundari, Ocky dan Dongoran, Johnson. 2020. "Pengaruh Komitmen Organisasi dan Kepuasan Kerja terhadap Kinerja Karyawan (Studi pada Perusahaan Daerah Air Minum (PDAM) Kota Salatiga". Jurnal Ekobis Dewantara. Volume 3, Nomor 1.

Darmawan, D. H. 2013. Prinsip-prinsip Perilaku Organisasi. Surabaya: Pena Semesta.

Hair, et al. 2006. Multivariate Data Analysis. Edisi 6. New Jersey: Pearson Education.

Handoko Hani. 2014. Manajemen Personalia dan Sumber Daya Manusia. Yogyakarta: Fakultas Ekonomika dan Bisnis UGM.

Husain, B.A. 2018. "Pengaruh Disiplin Kerja terhadap Kinerja Karyawan (Pada PT.Bank Danamon Tbk. Cabang Bintaro)". Jurnal Ilmiah Manajmen Forkamma.

Volume 1, Nomor 3, hlm 130-138.

Hasibuan, Malayu S. P. 2019. Manajemen Sumber Daya Manusia. Bumi Aksara: Jakarta.

Iskandar, 2018. "Pengaruh Kepuasan Kerja dan Pengawasan terhadap Disiplin Kerja Karyawan Akademi Kebidanan International Pekanbaru". Jurnal Akuntansi \& Ekonomika. Vol. 8, No. 2.

Kasino \& Indrayanti, Nurrul Fitri. 2020. "Analisis Pengaruh Motviasi Analisis Pengaruh Motivasi Kerja, Gaya Kepemimpinan, Disiplin Kerja terhadap Kinerja Karyawan PT. Siantar Top Waru-Sidoarjo". Jurnal Ecobisma. Volume 7 ,

Nomor 1.

Kurniasari, Rani \& Maulana, Ikhsan. 2019. “Analisis Kepuasan Kerja dan Motivasi Kerja terhadap Disiplin Kerja Karyawan”. Jurnal Widya Cipta. Volume 3, Nomor 2.

Lateiner, A.R. 2002. Teknik Memimpin Pegawai dan Pekerja. Jakarta: Aksara Baru.

Maharani, Sari dan Suhardi. 2020. "Pengaruh Budaya Organisasi Motivasi dan Disiplin Kerja terhadap Kinerja Karyawan pada Palm Springs Golf Country Club". Jurnal Aksara Public. Volume 4, Nomor 1, hlm. 184-196.

Mailana: Hayati, Diana dan Rahayu, Siti. 2018. "Pengaruh Disiplin Kerja terhadap Kinerja Karyawan pada di PT. Trio Motor Honda Warehouse Banjarmasin".DINAMIKA EKONOMI: Jurnal Ekonomi dan Bisnis. Volume 11, Nomor 1.

Manik, Sudarmin. 2017. "Pengaruh Kepuasan Kerja terhadap Disiplin Kerja Pegawai Kantor Camat Pendalian IV Koto Kabupaten Rokan Hulu". International Journal of Social Science and Business. Volume 1, Nomor 4, hlm. 257- 264. 
Mas'ud, Fuad. 2014. Survai Diagnosis Organisasional, Konsep \& Aplikasi. BP Universitas Diponegoro, Semarang.

Mokoagow, Z. M.; Soegoto, A. S. \& Sumarauw, Jacky S. B. 2020. “Pengaruh Kepuasan Kerja dan Pengembangan Karir terhadap Kinerja Karyawan pada PT. PLN (Persero) Wilayah Suluttenggo". Jurnal Emba. Volume 8, Nomor 1.

Nizar, Novil Cut. 2016. "Hubungan Kepuasan Kerja dengan Disiplin Kerja Pegawai Rektorat X di Padang”. Jurnal Psikologi Islam: Al-Qalb. Volume ～8, Nomor 2.

Pratama, Regi dan Nurbudiawati. 2016. " Pengaruh Motivasi Kerja terhadap Disiplin Kerja Pegawai di Kelirahan Sukakarya Kecamatan Tarogong Kidul Kabupaten Garut". Jurnal Pembangunan dan Kebijakan Publik. Volume 07, Nomor 02, hlm. 1019.

Purba, Deni Chandra; Lengkong, Victor P.K. dan Loindong, Sjendry. 2019. "Analisis Pengaruh Kepuasan Kerja, Motivasi Kerja dan Disiplin Kerja terhadap Kinerja Karyawan pada Perusahaan Umum Percetakan Negara Republik Indonesia Cabang Manado". Jurnal EMBA. Volume 7, Nomor 1.

Rahmania, Fadhila dan Widawati, Lisa. 2020. "Hubungan antara Kepuasan Kerja dengan Disiplin Kerja Karyawan bagian Quality Control (Studi Korelasi menggunakan Two Factor Theory Herzberg pada PT. X)". Prosiding Psikologi.

Volume 6, Nomor 1.

Robbins, Stephen P. dan Timothy A. Judge. 2009. Perilaku Organisasi: Organizational Behavior. Jakarta: Salemba Empat.

Rohana \& Akos, Misransyah. 2019. "Pengaruh Motivasi dan Kepuasan Kerja terhadap Disiplin Kerja Pegawai Administrasi di RSUD Ulin Banjarmasin". Jurnal Administraus. Volume 3, Nomor 3.

Safitri, Debby Endayani dan Sutjahjo, Gandhi. 2020. “Pengaruh Motivasi dan Disiplin Kerja Pegawai Negeri Sipil”. Jurnal Dimensi. Volume 9, Nomor 1.

Saputra, Trio. 2019. "Pengaruh Motivasi Kerja terhadap Disiplin Kerja Karyawan pada Hotel Permai Pekanbaru”. Jurnal Benefita. Volume 4, Nomor 2, hlm. 316-325.

Sedarmayanti. 2017. Manajemen Sumber Daya Manusia. Bandung: Refika Aditama.

Sinungan, M. 2014. Produktivitas: Apa dan Bagaimana. Jakarta: Bumi Aksara.

Sugiyono. 2010. Metode Penelitian Pendidikan: Kuantitatif, Kualitatif Dan R\&D. Bandung : CV Alfabeta.

Syardiansah \& Utami, Melati Putri. 2019. "Pengaruh Lingkungan, Disiplin dan Motivasi Kerja terhadap Kinerja Karyawan PT. Pati Sari di Aceh Tamiang". Jurnal Konsep Bisnis dan Manajemen. Volume 5, Nomor 2. 
Philanthropy Journal of Psychology

Vol 5 Nomor 1 (2021), 31-46

ISSN 2580-6076 (Print), ISSN 2580-8532 (Online)

Syarkani. 2017."Pengaruh Disiplin Kerja terhadap Kinerja Karyawan pada PT. Panca Konstruksi di Kabupaten Banjar". Jurnal Ilmiah Ekonomi Bisnis. Volume 3, Nomor 3, hlm 365-374.

Tyas, Rima D. \& Sunuharyo, B. S. 2018. “Pengaruh Disiplin Kerja dan LingkunganKerja terhadap Kinerja Karyawan”. Jurnal Administrasi Bisnis. $\quad$ Volume 62, Nomor 1. 